\title{
Striden om Sli-silden: en økonomisk strid om sildefiskeriet på Slien 1805-1935
}

\author{
af Nils Vollertsen
}

Striden om Sli-silden, der startede i 1805 og varede helt frem til 1935, er ikke kun en endeløs strid om privilegier, men afspejler også et samfund i opbrud. Den gamle opdeling af sildefiskeriet på Slien mellem tre parter: fiskerlavet på fiskerlejet Holmen i Slesvig, kronen og adelen blev således op igennem 1800-tallet truet af et stadig større antal bierhvervsfiskere, der især tilhørte to grupper. Den ene var landarbejderne og daglejerne, som efter udskiftningen var blevet tvunget til, frem til ca. 1800-1805 at flytte bort fra det godsrige østlige Angel og Svans til landsbyerne langs med Slien i håb om, her at finde bedre levevilkår; og den anden Arnæs-skipperne med deres mandskab, der på grund af nedgangen i Arnæs' skibsfart efter 1845-1850 blev tvunget ud i net- og vodfiskeriet på Slien. Dette udløste op igennem 1800-tallet en lang række stridigheder, som forst sluttede i 1935.

Samfundet var i opbrud, og her var udskiftningsprocessen, der i Kongeriget startede ca. 1790 og blev afsluttet i 1840'erne, kun starten på en demokratisering og liberalisering af samfundet, som i 1857 fik sit foreløbige højdepunkt i næringsfrihedsloven. I Preußen vedtoges den først i 1867. Op igennem 1800-tallet skete der altså en ændring af samfundet, bort fra en privilegieorienteret og henimod en friere økonomisk struktur. I takt hermed bliver Slesvigs fiskerlav nødt til, også at lade andre end lavets egne fiskere fiske efter sild på Slien. Som det ses, havde striden om Sli-silden ikke kun økonomiske årsager, men fik også en række sociale, kulturelle og magtpolitiske konsekvenser. Det er det, jeg vil vise.

\section{Striden 1805-1865: Med magt skal privilegier forsvares}

Med højkonjunkturen og befolkningstilvæksten i 1780-1800 steg ikke kun erhvervsfiskernes tal i Slesvig, men også mængden af bierhvervsfiskere langs med Slien, hvis fangstmetoder blev stadigt mere effektive. 
Følgen blev et øget fiskeri, som forringede Slesvig-fiskernes fangst så kraftigt, at de blev økonomisk trængte. I konkurrence til Slesvigfiskerne leverede bierhvervsfiskerne silden direkte ind til Slesvig, hvor de solgte den til dumpingpriser. De nærmest kontrollerede markedet $\mathrm{i}$ Slesvig. Ved at levere silden direkte ind til Slesvig udfyldte de et hul, der var opstået siden 1770-1775, da Slesvigs rolle som stabelplads for sildeeksporten til bl.a. Hamburg, Sachsen, Thüringen og Kassel var begyndt at svinde. Siden da var Slesvigs fiskere mere og mere gået over til at lande silden på fangstpladserne, hvorfra den så blev fragtet til Kappel og Egernførde til røgning. Herfra blev Sli-silden videresendt til markederne mod syd.

Konkurrencen betød, at Slesvig-fiskernes fangster blev reduceret

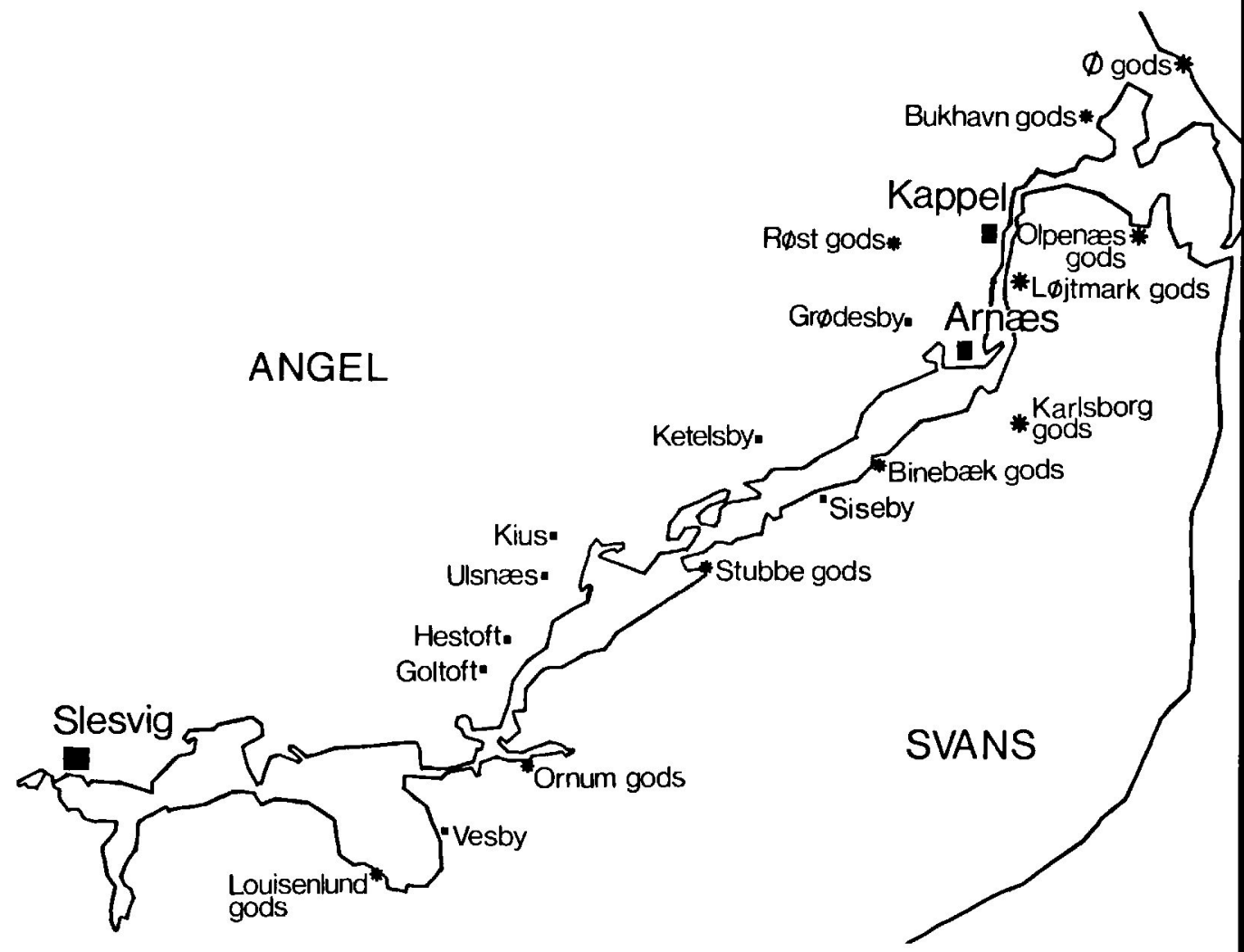

Kort over de lokaliteter og godser, Slesvigs fiskerlav forte strid imod. Selv om de adelige godsejere $i$ det store og hele holdt sig uden for denne sene fase af striden om Sli-silden (1805-1935), så tyder en del dog på, at de bag kulisserne gjorde hvad de kunne for at hindre Slesvigs fiskerlav $i$ at styrke dets $i$ forvejen starke lokale stilling. 
med $80 \%$. Derfor udvidede de fiskeriet på kronens fiskegrunde og lige ud for Slesvig i en sådan grad, at kronen greb ind. Dette skete i 1805 , da den nedsatte Sli-kommissionen, som skulle varetage Slesvigfiskernes og adelens interesser mod bierhvervsfiskerne i striden om Slisilden. Dens opgave var således at sikre fiskerlavets og adelens indtægter fra sildefiskeriet på Slien. Derfor opfordrede den alle, der mente at have ret til fiskeri på Slien, til at gøre deres krav gældende. Der meldte sig 43.

Af dem gjorde de adelige godsejere krav på retten til at have sildegærder, til at udøve vodfiskeriet i den nedre Sli (fra Arnæs til Sli-mundingen) og til at drive småfiskeri. Småfiskeriet tjente godsernes bønder og øvrige ansatte som kosttilskud og mindre biindtægt, mens sildegærderne og vodfiskeriet hørte til blandt godsernes vigtigste indtægter. Fiskerlavet i Slesvig krævede (jvf. Christian 1. Sli-brev 1480) retten til fiskeri på Slien og en mil ud i Østersøen, dog undtaget adelens fiskerirettigheder og kronens fiskegrunde; og den danske stat (rentekammeret) reserverede sig samtlige fiskerirettigheder på Slien. Dette krav gav staten dog igen afkald på i 1820 .

Arnæs mente (jvf. flækkeprivilegiet 1667) at have ret til at fiske med net og snøre helt op til Sli-mundingen. Man forsømte dog at afgrænse den del af Slien, hvor Arnæs' fiskerirettigheder gjaldt og at forklare, hvorvidt der ved »Netze« (net, sættegarn) også var tale om »Zugnetze» (vod, drivgarn). Siden 1843 kom striden med Arnæs derfor især til at dreje sig om dette problem.

Den største gruppe, halvdelen, omfattede boelsmænd, små selvejere, fæstere og parcellister, hvis lodder grænsede ned mod Slien, og som de drev småfiskeri ud fra. Småfiskeriet var deres eneste mulighed for at holde sig oven vande, men som enkeltpersoner stod de meget svagt over for de organiserede vodfiskere i Slesvig. Dette kom til at præge striden. Kommunerne stod som organiseret enhed straks stærkere over for fiskerlavet i Slesvig. Også dette prægede striden. I den forbindelse gjorde Vesby krav på at fiske over hele Slien, hvilket lagde op til årtiers strid med fiskerlavet. Også Goltoft, Hestoft, Kius og Ulsnæs mente at være i deres fulde ret til at fiske småt langs med de jorder, der grænsede ned mod Slien. De tog siden mere eller mindre del i striden om Slisilden.

Sli-kommissionen valgte intet at foretage sig. Slesvigs magistrat, den egentlige initiativtager, var altså ikke kommet et skridt videre. Allerede i 1805 stod det derfor klart, at Sli-kommissionen ikke varetog den opgave, den havde fået pålagt. 
I perioden efter Napoleons-krigenes afslutning (1814-1825) blussede konflikten atter op, denne gang foranlediget af Stubbe gods, hvis fiskere Slesvigs fiskerlav klagede over fiskede ulovligt på Slien. Slesvigs magistrat bad derfor i 1816 Sli-kommissionen om at undersøge fiskerirettighederne. Kommissionen konstaterede, at de rettigheder, Slesvigs fiskerlav gjorde gældende, var i modstrid med både adelens, den danske stats, Arnæs', Kappels, kommunernes og de privates. Det var grunden til, at man bad magistraten om at redegøre for, hvilke rettigheder der skulle ses nærmere efter i sømmene. Længere nåede man ikke.

Slesvigs magistrat spillede ikke ud, fordi man ville undgå, via forhastede retssager at skulle give afkald på nogle af byens egne privilegier; ej heller ville man risikere, på grund af dyre retssager at skulle optage store lån. Slesvigs økonomi var fortsat dårlig, Slesvigs vodfiskere økonomisk trængte, og magistraten var godt klar over, at dens magtsfære ikke rakte langt i forhold til adelens. I 1819 stod det klart, at alle

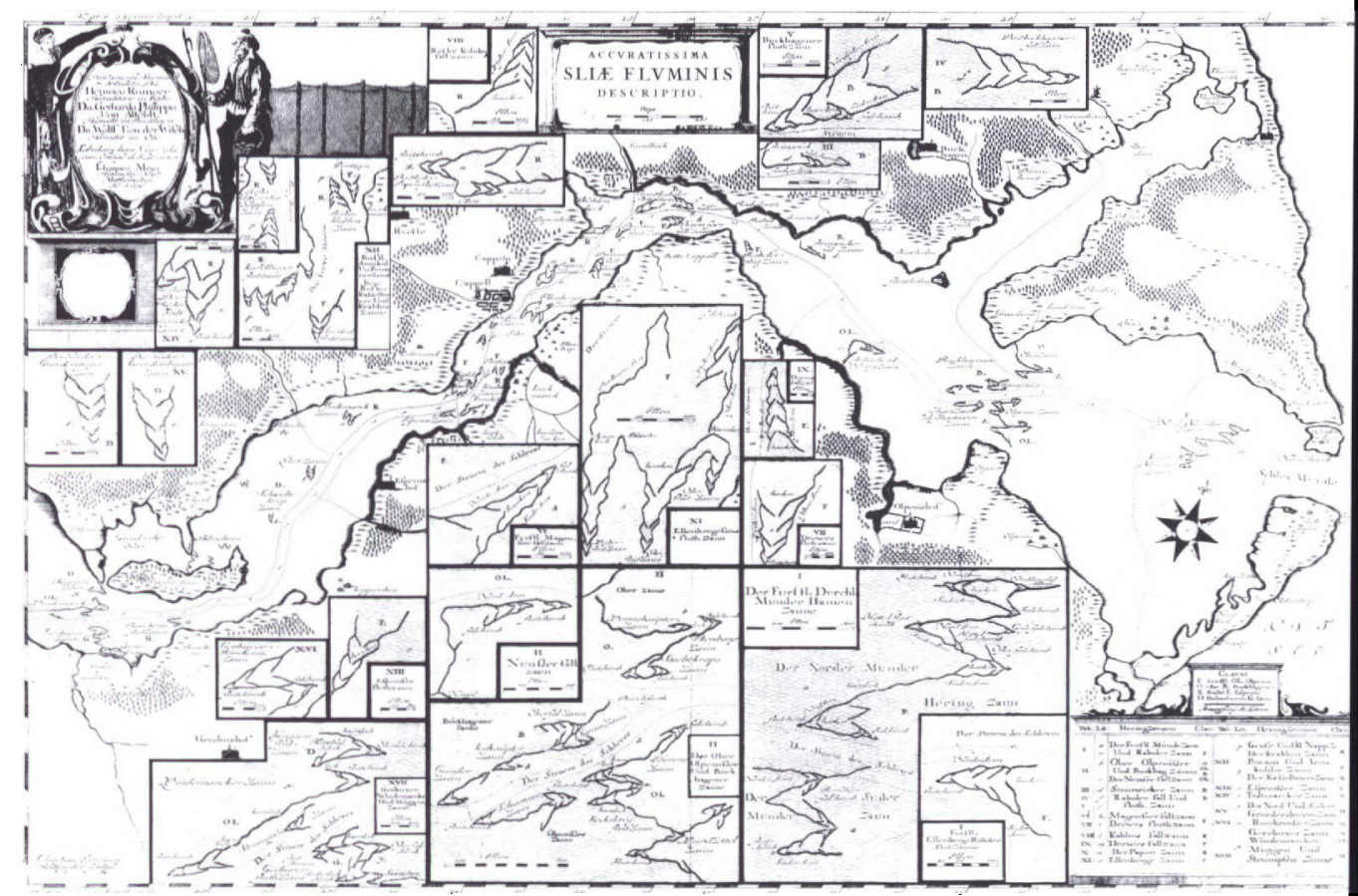

Kartografen Johannes Mejers kort fra 1649 over sildegarderne på den nedre del af Slien, der omfatter området mellem Arnas og Sli-mundingen. De sildegarder, der var tilbage på denne strakning, blev $i 1869$ eksproprieret af den preussiske regering. 
bestræbelser på at løse striden om Sli-silden løb ud i sandet, fordi initiativerne stødte på stærk modstand fra de magtfulde adelige godsejere. Det var grundene til, at Slesvigs magistrat søgte at undgå enhver konflikt med godsejerne. Sagen endte med, at overretten i 1823 gav lodsejerne fra 1805 medhold, og Slesvig tabte. Man lod nu sagen ligge.

I stedet kom det 1820-1860 i perioder til strid med kådnerne (daglejerhusmændene) i Vesby, som under 1820'ernes landbrugskrise forøgede deres fiskeri på Slien, hvilket bragte dem i et spændingsforhold til vodfiskerne i Slesvig, der var organiseret i Slesvigs fiskerlav. Vesbyfiskerne havde også lidt handel af røgede fisk til Frederiksstad, Tønning og Heide. Nogen egentlig konkurrent til Slesvigs vodfiskere var der dog på ingen måde tale om, dertil var fiskerne i Vesby alt for små. Alligevel var vesbyernes fiskeri en torn i øjet på fiskerlavet i Slesvig, da tabet af Hamburg-markedet i 1810'erne og 1820'ernes krise havde tvunget lavet til at fastholde sine indtægter ved at fæstne sin $i$ forvejen ret stærke stilling på sildemarkedet. Dette skete ved, at lavet fra 1820 forpagtede kronens fiskegrunde og fra ca. 1835 adelens vodfiskeri på Slien. Fiskerlavet var dog stadig økonomisk trængt. I den situation lukkede lavet øjnene for det sociale og økonomiske interessefællesskab mellem småfiskerne i Slesvig, som stod uden for fiskerlavet, og Vesbys småfiskere. Dette svækkede på langt sigt lavet indadtil: i forhold til netfiskerne på Holmen, som fiskede småt, og udadtil: især over for Arnæs-skipperne, der blev Slesvig-fiskerlavets hovedmodstander i striden om Sli-silden.

Fiskerne i Vesby fortsatte fiskeriet. De så ikke nogen mening i, at Slesvigs fiskerlav havde eneretten til Sli-fiskeriet. Det var jo til skade for andre fiskere. I 1828 forbød Sli-kommissionen så vesbyernes småfiskeri; en afgørelse, overretten stadfæstede i 1831. I årene fremover faldt der ro over sagen, men da var konjunkturerne også blevet bedre. Landarbejderen, daglejeren og kådneren kunne dog ikke overleve i det fortsat ekstensive slesvigske landbrug, der kun brugte ham som sæsonarbejder; og da Vesby netop bar præg af dem, tog striden igen fart o. 1840. For vesbyerne gjaldt det om at overleve; de havde kun lige til dagen og vejen, og enkelte endnu mindre. Derfor fiskede de. Sli-kommissionen reagerede ved at give dem bøder, og beslaglagde endda 1857 samtlige sildenet med fangst. Det knækkede vesbyerne, og i 1860 magtede de ikke at betale bøderne længere. Det gav ro.

De kapitalstærke Arnæs-skippere, der 1843-1865 indledte en ny strid om sildefiskeriet på Slien, var dog stærkere end vesbyerne. To parallelle tendenser kendetegner således udviklingen om Sli-silden i 1840'erne: 


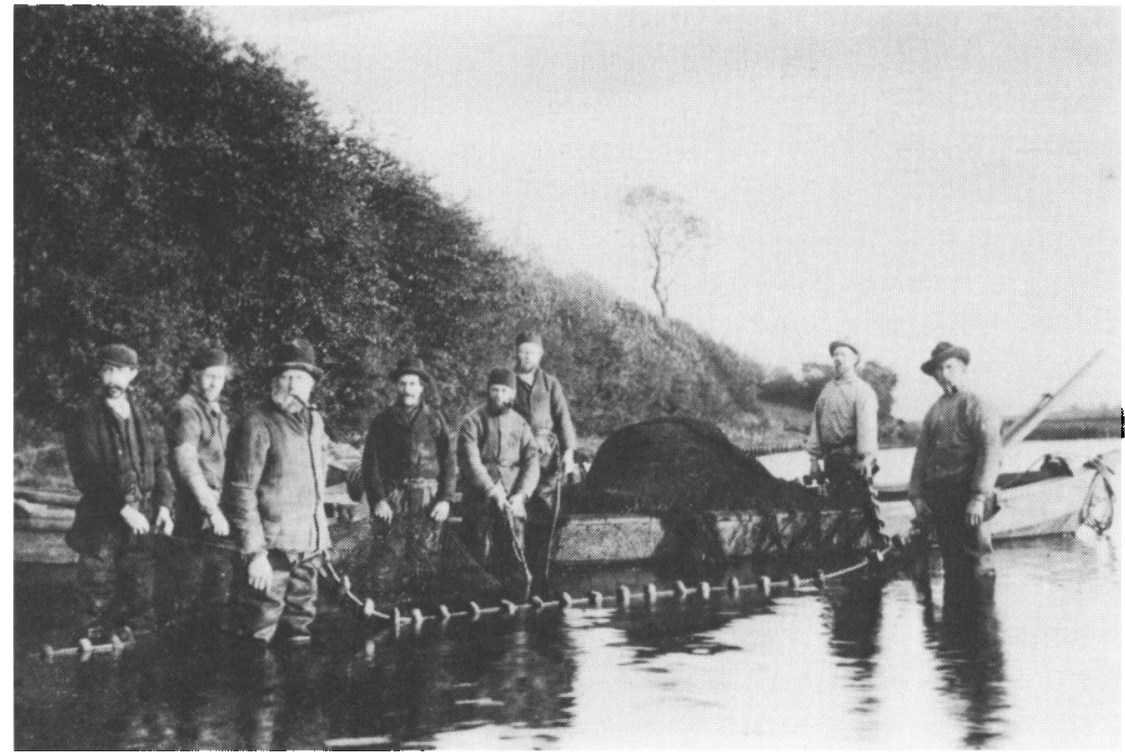

I Arnas fandtes o. 1900-1910 kun ét vodfallesskab, som fiskede med vod (drivgarn) og som levede af fiskeriet. Langt de fleste Arnas-fiskere fiskede dog småt med net (sattegarn) eller snorer. Deres fiskeri drev de som bierhverv. Ca. 1910.

nedgangen i Arnæs' skibsfart og den begyndende afmonopolisering af sildefiskeriet på Slien. Støttet af de større skippere, der så en økonomisk fordel i sildefiskeriet, fik dette de mindre Arnæs-skippere til at starte et net- og vodfiskeri på Slien. Det satte dem i et modsætningsforhold til fiskerlavet i Slesvig, som trods alt stadig beherskede markedet. Lavet gjorde alt for at hindre, at Arnæs-skipperne gjorde indhug i dets indtægter og deraf følgende lokale magtstilling. Silden udgjorde lavets magtgrundlag. Også fiskerlavet i Kappel reagerede imod, at der i Arnæs-skipperne voksede en ny konkurrent frem.

Skipperne i Arnæs var godt klar over deres stilling. De vidste, at det var deres økonomiske styrke, der gjorde, at de kunne fiske sild uantastet af fiskerlavet i Slesvig. Netop dette frygtede Slesvigs vodfiskere allermest, da det ville få arnæsserne fra de lavere sociale lag til også at fiske. Hvis de havde heldet med sig, frygtede man, ville det udløse en lavine blandt landproletariatet langs med Slien. Det skete nu ikke, men fiskerlavet i Slesvig måtte se i øjnene, at skipperne i Arnæs var stærke nok til, uden anden hensyntagen at fiske silden væk for næsen af dem. Dem: det var vodfiskerne i Slesvigs fiskerlav. Arnæs-fiskerne 
var en trussel mod disse vodfiskere fra Slesvig, der levede af fiskeriet. Fiskerne i Arnæs, som også var skippere, fiskede især på den øvre Sli (mellem Slesvig og Arnæs); og da det netop var her, de bedste fangstpladser lå, udgjorde området det økonomiske grundlag for Slesvig-vodfiskernes og dermed Slesvig-fiskerlavets stærke lokale stilling.

Også erhvervsfiskerne i Kappel og forpagteren af Karlsborg gods' sildefiskeri klagede over Arnæs-skippernes ulovlige fiskeri. Intet hjalp: hverken bøder, beslaglæggelse af net eller en overretsdom, der som vanligt faldt ud til Slesvig-fiskernes fordel. Skipperne i Arnæs nøjedes med, uforstående at trække på skuldrene og hævde, at de ikke brugte vod, men store net.

Nedgangen i Arnæs' skibsfart havde frigjort en del arbejdskraft fra søen. I takt med, at det skete fra 1840 'erne, gik søfolkene over i fiskeriet. I 1846 fiskede således 40-50 arnæssere, heraf ca. 30\% skippere, hvilket svarede til godt en fjerdedel af alle beskæftigede i skibsfarten. Især de små skippere og deres mandskab var sårbare, fordi de ikke længere tjente nok ved skibsfarten til kun at leve af den. Derfor reagerede de så hårdt over for Slesvigs fiskerlav, der gang på gang prøvede at hindre deres fiskeri.

Med tiden blev det fiskerlavet i Slesvig for meget, og i 1846 klagede lavet til amtmanden. Lavet var bange for, at flere adelige godser, der i mange år ikke havde gjort brug af deres fiskerirettigheder, på ny ville gøre dem gældende. Amtmanden, som repræsenterede staten, lod derpå for en tid et militærkommando på 35 jægere privat indkvartere i Arnæs. Dette virkede efter hensigten, idet det delte arnæsserne $i$ to. Den ene part mente, det ulovlige sildefiskeri burde holde op, mens den anden blot fortsatte fiskeriet. Da Arnæs-fiskerne på trods af politiets afpatruljeringer af området omkring Arnæs øgede fiskeriet, blev striden tilspidset 0.1850 . Arnæs-skipperne fiskede nu med 14 vod, hvilket var næsten lige så mange som Slesvig-fiskernes. Desuden gav overretten i 1850 Arnæs' fiskere medhold. Sli-kommissionens bekendtgørelse af 1853 var således et tydeligt forsøg på at føre tilstandene tilbage til retsforholdene, som de var i 1805. Også Sli-kommissionen stod magtesløs over for Arnæs-skippernes fiskeri, så længe man endnu ikke var nået til nogen endelig afgørelse $i$ striden om Sli-silden.

I øvrigt svækkede uenigheden om, hvorvidt Slien hørte under amtmandens, overrettens eller Slesvigs jurisdiktion, Slesvigs vodfiskere over for de fiskende Arnæs-skippere. I dette juridiske pindehuggeri varetog amtmanden Slesvig-fiskerlavets interesser og overretten Arnæsskippernes, mens Slesvigs magistrat blot fulgte sagen. Det førte til, at 


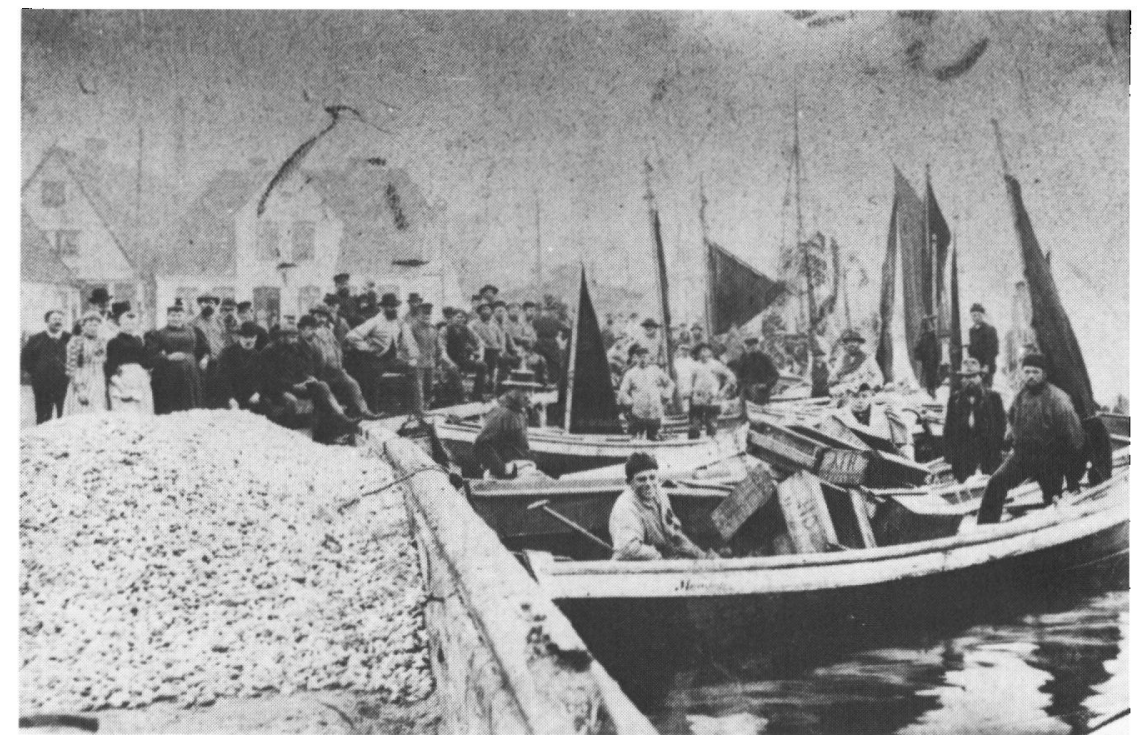

Kappels småfiskere, som ses her, fiskede kun med net. Ca. 1880.

amtmanden fortsatte med at udstede bøder og forbud mod arnæsserne, og overretten med at ophæve dem. Frem til 1865 gik striden dog også ud over de førhen så kapitalstærke større og mindre Arnæs-skippere, som mere og mere skiftede over til fiskeriet. Ret beset var striden mellem vodfiskerne i Slesvig og skipperne i Arnæs ikke andet end en kamp for at bevare hver deres rolle som stærke lokale økonomiske faktorer, og i den havde de begge lidt økonomiske tab.

Omsider tog det slesvigske ministerium sagen op for at få løst de sociale problemer, striden om Sli-silden havde skabt. Det var i 1858. Slet ikke så få lodsejere langs med Slien led social nød, fordi Slesvigs fiskerlav håndhævede sin eneret til Sli-fiskeriet så strikt. Desuden agtede ministeriet at ekspropriere sildegærderne, eftersom de gav kolossale underskud (årlige udgifter 10000 rd., indtægter kun 2000 rd.) og tilmed var til gene for fiskeriet.

I det hele taget, mente ministeriet, var eneretten til Sli-fiskeriet en forældet sag, i strid med liberalismens grundtanke om den fri konkurrence. Overført på Slien betød det, at alle havde ret til, frit at fiske i fjorden. Dertil kom, at monopolet stod i vejen for en rationel udnyttelse af sildefiskeriet »og således af en velstandskilde for landet $i$ at flyde så rigeligt, som det ellers kunne ventes«. Ministeriet gik derfor ind for en 
total frigivelse af Sli-fiskeriet mod, at kommunerne betalte en fast årlig afgift til den kongelige kasse.

Sli-kommissionen var på sin vis enig med ministeriet, men frarådede dog en total frigivelse af sildefiskeriet på Slien, da det ville true Slesvigfiskernes eksistens. Med Slesvig-fiskerne mener jeg alle fiskerlejet Holmens fiskere; og det både vodfiskerne i fiskerlavet og netfiskerne udenfor. I stedet anbefalede kommissionen ministeriet at give delvise koncessioner til vodfiskeriet og frigive netfiskeriet helt. Fiskerlavet i Slesvig gik imod forslaget. For lavet gjaldt det, som altid, jo netop om at bevare silden som det økonomiske grundlag for Slesvig-vodfiskernes eksistens.

Efter 1864 nyordnede heller ikke den preußiske regering sildefiskeriet på Slien, da modstanden fra Sli-kommissionen, der trods alt fortsat varetog fiskerlavets interesser i Slesvig, alligevel var for stor. Desuden forbød kommissionen igen i 1865 folk fra Arnæs, Kappel og Masholm at fiske på Slien. Det eneste, der skete, var, at Preußen i 1869 eksproprierede sildegærderne $\mathrm{i}$ den nedre Sli; men striden fortsatte.

\section{Striden 1869-1913: Slesvig-fiskerlavets og Arnæs- skippernes stærke lokale magtstilling går tabt}

Den økonomiske udvikling betød, at den fri konkurrence om Sli-silden blev en realitet mod Sli-kommissionens og Slesvig-fiskerlavets vilje. I den forbindelse var det ikke uden betydning, at Arnæs' handel, der jo udgjorde Arnæs-skippernes økonomiske grundlag, i løbet af 1860'erne og 70'erne gik stærkt tilbage; så stærkt, at Arnæs' handel o. 1900 var en saga blot. For Slesvigs fiskerlav gjaldt, at de foregående års fiskeristridigheder havde tæret stærkt på lavets og dermed også vodfiskernes økonomi. Faldende indtægter kombineret med flere fiskere på Holmen i Slesvig endte i 1870'erne ikke kun i intern strid mellem organiserede vodfiskere og uorganiserede netfiskere, men i 1880 'erne og 90'erne også mellem de store og små Slesvig-vodfiskere. Disse interne modsætninger svakkede Slesvigs vodfiskere.

De dårlige konjunkturer, Slesvig-Arnæs fiskeristriden og Slesvigfiskernes interne strid svækkede efter $1869 \mathrm{i}$ den grad Arnæs-skippernes og Slesvig-fiskerlavets førhen så stærke lokale stilling, at ingen af dem i 1880 'erne længere var stærke nok til at kunne hævde deres tidligere lokale dominans. Slesvigs vodfiskere tjente således kun 600-700 M årligt. De havde altså ikke til mere end småfiskerne i den nedre del af Slien. 


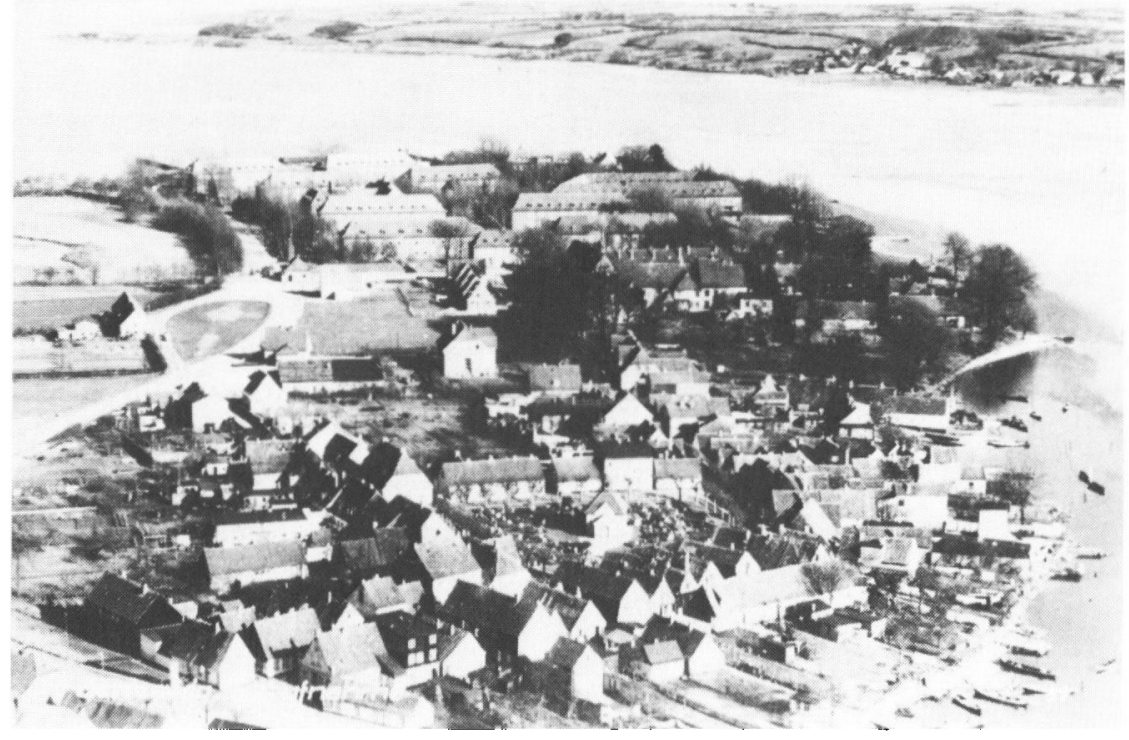

Fiskerlejet Holmen ved Slesvig foran, og kasernen Die Freiheit bagved i billedet. Kasernen blev bygget på holmernes tidligere nettorreplads Friheden. Fra 1939-1940.

Kappels erhvervsfiskere, som længe havde holdt sig uden for Slisildstriden, tjente derimod med årligt godt 1000-1200 M (1885-1886) rimeligt godt. Da Kappel-fiskerne i 1870 'erne havde intensiveret deres vodfiskeri, og der fra 1880 'erne i det hele taget blev færre sild i Slien, afkrævede Arnæs derfor i 1888 Slesvig ret til at fiske med alle slags garn, også med drivgarn (vod, Zugnetze) på hele Slien. Slesvig gik imod. Arnæs' småfiskere og Slesvigs vodfiskere havde tydeligt nok kun et for øje: at klare sig bedst muligt igennem en økonomisk vanskelig tid. Slesvig-, og nu også Arnæs-fiskerne, var jo anvist på fiskeriet som levebrød. I Kappel gik fiskeriet også tilbage, men her var der færre erhvervsfiskere, som tilmed havde lettere ved at klare sig, fordi silden jo først nåede til dem, før den kom til den øvre Sli, hvor Slesvig- og Arnæs-fiskerne fiskede. Kappel havde 15 erhvervsfiskere, som fiskede med vod. Desuden blev de få bierhvervsfiskere, der måtte være i Kappel, hurtigt opsuget af lokale industriprægede foretagender, som flækken tiltrak.

Resultatet af den genoptagne Slesvig-Arnæs fiskeristrid blev, at landsretten i 1888 anerkendte Arnæs' ret til at fiske småt på den øvre Sli, mens overlandsretten i 1890 indskrænkede retten til kun at galde 
ned til Bustorp bredning. Disse afgørelser betød i princippet et forbud mod Arnæs-fiskernes vodfiskeri på Slien. Ingen af parterne havde i 1890 kræfter til flere retstrætter, hvilket frem til 1917 førte til ro i striden med Arnæs. Dertil kom, at Arnæs fra ca. 1900 og frem til 1914 ikke længere var anvist på sildefiskeriet, da perioden bragte et mindre opsving for flækken som kursted, og småfiskerne i Arnæs derfor gennemgående blev opslugt af turistindustrien.

Fra ca. 1895 til 1905 søgte silden næsten helt bort fra Slien og ned i Kieler-kanalen. De ret få sild, der blev tilbage, fandt efter opførelsen af jernbanebroen ved Lindånæs kun hen til fiskegrunden Höltog nær Binebæk gods, fordi brobyggeriet havde ødelagt gydepladserne ved broen. Slesvig-vodfiskernes eksistens afhang derfor i stadigt stigende grad af Höltog, der efter 1881 blev den bedste fangstplads på den øvre Sli. Netop Höltog havde Binebæk gods dog forpagtet ud til kådnerne Rudolf og Richard Green, der årligt kun tjente $700 \mathrm{M}$ netto. Det var ikke ret meget. Green-brødrene var selvsagt interesseret $i$ at holde indkomsten oppe. Derfor holdt de dels materialeudgifterne nede ved også selv at fiske med snører og stange ål; og dels forstørrede de i takt med Slesvigs vodfiskere Binebæk-voddet fra 160 fod i 1844 til $350 \mathrm{i}$ 1899. I 1898-1905 førte dette til strid med Slesvigs fiskerlav.

Mens familien Green fra 1860 'erne havde været ene om forpagtningen af Binebæk gods' vodfiskeri, forpagtede brødrene Green fra 1888 fiskeriet sammen med godset; og de fiskede ikke kun med vod, men også småt. Kritisk blev det først, da Rudolf og Richard Greens dårlige $ø$ konomi tvang dem over i småfiskeriet på hele Slien. Slesvigs fiskerlav mente, at der var tale om ulovligt fiskeri, da lavet jo havde eneretten på fiskeriet $\mathrm{i}$ den øvre Sli, som Binebæk gods lå ud til. Retten gav fiskerlavet medhold, hvormed sagen i første omgang var bragt ud af verden.

Striden blev tilspidset, da hofchef von der Recke på Binebæk gods i 1898 brugte sin politimyndighed til at gribe ind i sagen og idømme Slesvigs vodfiskere en bøde. Striden fik derved en helt anden karakter. Den drejede sig ikke længere om småfiskeriet på Slien, den sag var afgjort, men om vodfiskeriet på Höltog. Godset mente, at Höltogs forpagtere havde ret til at fiske på vodpladsen hele året rundt; og ikke, som vodfiskerne i Slesvig påstod, at forpagterne af Binebæk gods' fiskeri kun havde ret til at fiske, når de selv (Slesvigs vodfiskere) ikke var til stede. Var de derimod det, skulle forpagterne af godsets fiskeri vige pladsen. Derfor besatte Slesvig-vodfiskerne Höltog, hvorved de fuldstændigt hindrede forpagterne i at fiske på stedet. Slesvigerne gik 


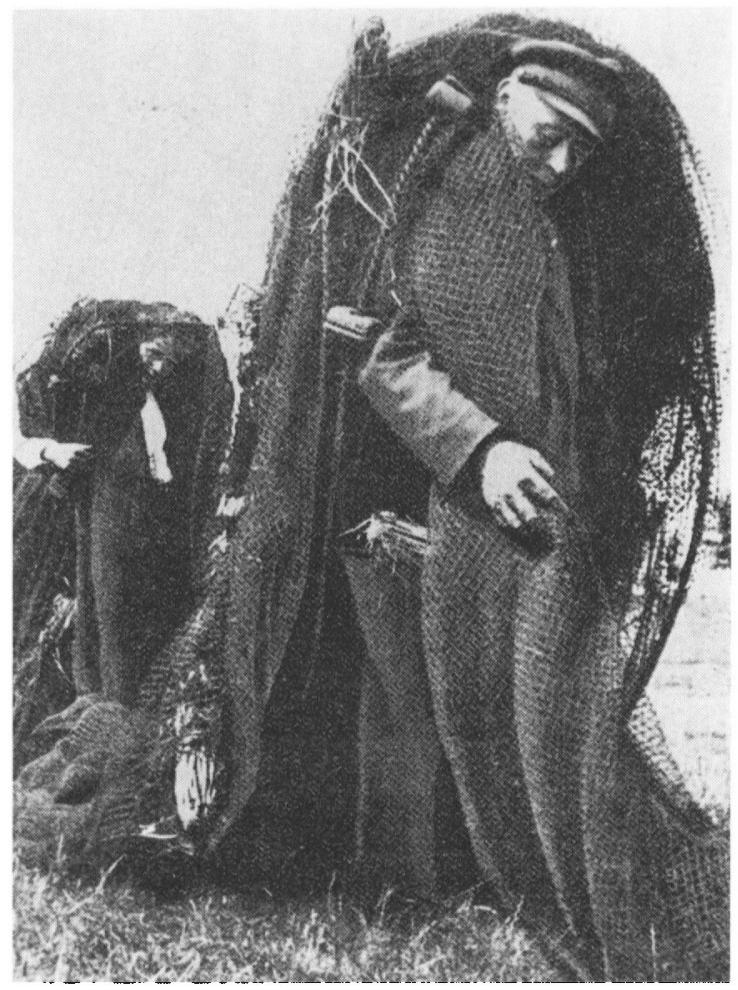

Voddet slabes fra nettorrepladsen Friheden ned til badene ved Slien. Ca. $1920-1930$.

endda så vidt som til at lægge sig på lur, såsnart Binebæk-fiskerne var i syne og så starte fiskeriet, når de nærmede sig. En konfrontation var uundgåelig.

Domstolene havde det sidste ord. Ikke kun lands- og overlandsretten i 1903, men også højesteretten i Leipzig forbød i 1905 fiskerlavet på Holmen i Slesvig at forstyrre godsets fiskere i deres fiskeri på Höltog. Ingen af instanserne rørte dog ved lavets rent formelle eneret til Slifiskeriet.

Fiskerlavets dage som stærk lokal faktor var talte. Kræfterne var sluppet op. I stedet begyndte lavet i 1902-1913 at trættes med Goltoft, Ulsnæs, Grødesby og Ketelsby kommuner. Problemet var, at kommuneforstanderne siden den preußiske fiskerilovs ikrafttræden 1874 havde udstedt fiskekort, som gav tilladelse til at fiske småt på hele Slien. Slesvigs fiskerlav syntes, kommuneforstanderne var for rundhåndede med at udstede disse fiskekort. Lavets fiskere mærkede nu særlig hårdt, hvor skidt det gik dem. De praktiserede endda selvtægt ved at fjerne 


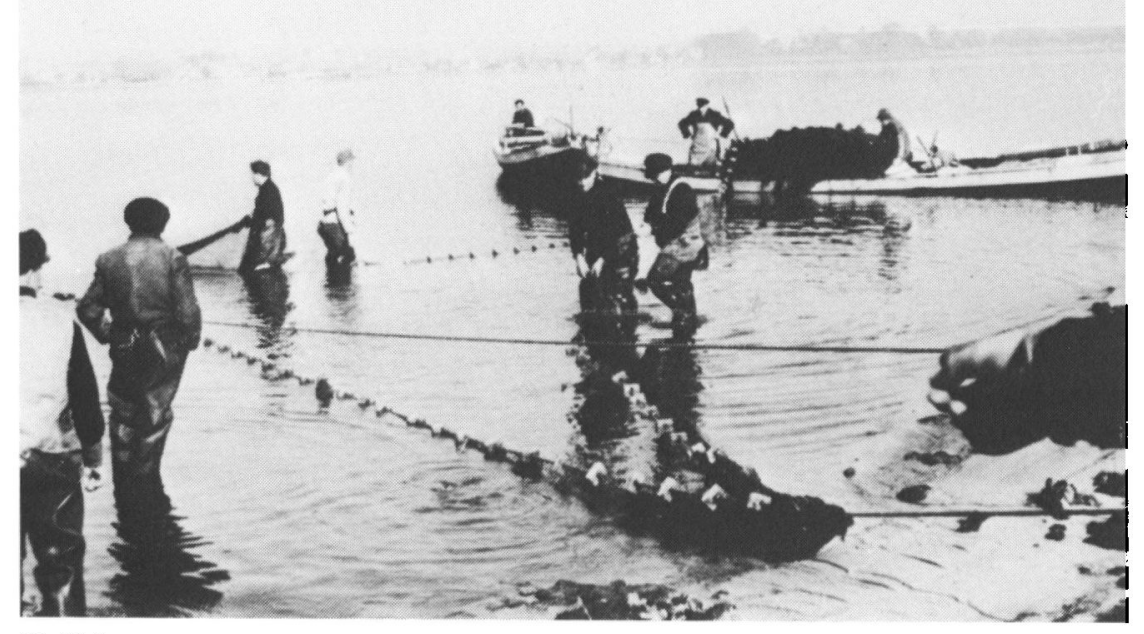

Vodfiskeri om vinteren, inden Slien er frosset til. Voddet trakkes i land. Ca. 1930.

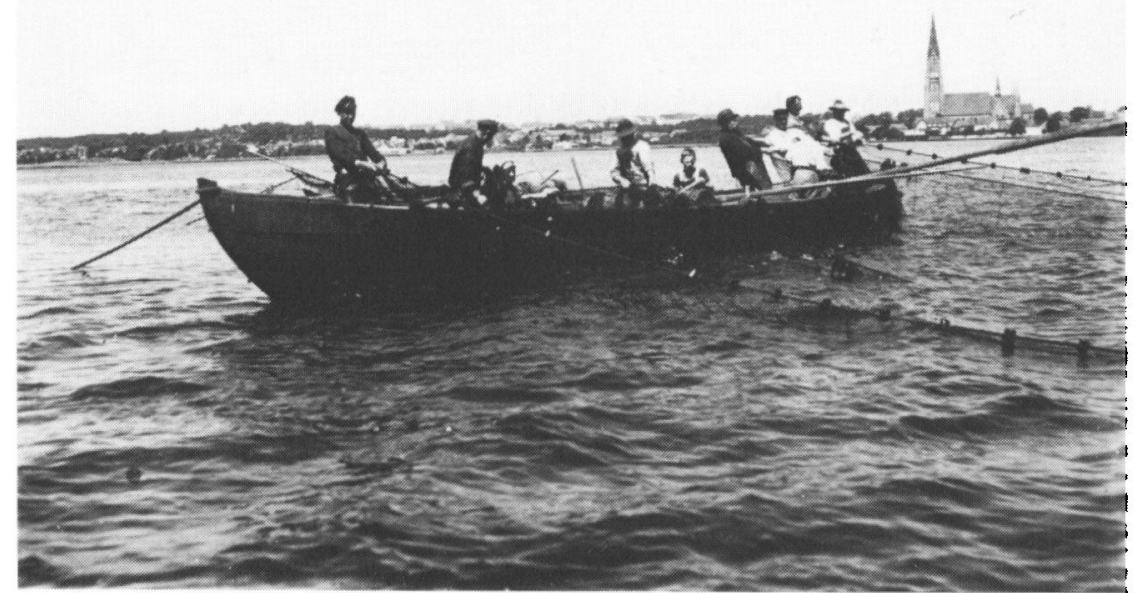

Vodfallesskab af Slesvig-fiskere trakker vod i land. Ca. 1935.

småfiskernes fiskekurve og åleruser. Derpå anklagede de kommunernes småfiskere for ulovligt fiskeri, som til gengæld anklagede slesvigerne for tyveri. 
Husmanden, aftægtsmanden, parcellisten og landarbejderen, som fiskede småt, stod fuldstændigt uforstående over for retssagen, der førtes hen over hovederne på dem: "Jeg har aldrig tænkt på, om fiskeriet var forbudt eller kun tilladt i et vist omfang. Når jeg glibbede, var jeg sammen med en ældre mand og gjorde, som han sagde - Jeg troede, jeg havde ret til at fiske småt, ellers havde mine forældre vel ikke givet mig lov til det; men grunden til, at jeg var berettiget dertil, kendte jeg ikke - Jeg har altid troet, at enhver, som havde lyst til det, kunne fiske småt; og jeg vidste heller ikke, at slesvigerne havde en særlig ret til Sli-fiskeriet - Jeg troede, vi havde ret til at fiske småt; det har mine forældre og bedsteforældre jo også gjort « (oversat fra tysk).

Disse folk fiskede småt, fordi der var tradition herfor $i$ familien, og nu ville Slesvigs vodfiskere med deres privilegier $\mathrm{i}$ hånden hindre dem i fiskeriet. Det kunne de hverken forstå eller acceptere. Uden tvivl har de ikke mærket synderligt til retssagen; kun, når der var optræk til slagsmål med Slesvigs vodfiskere. Som den svage part, de var, fortrak de sig så; men fortsatte fiskeriet, så snart slesvigerne vendte ryggen til. For Slesvigs vodfiskere gjaldt det fortsat om at skulle nå igennem en økonomisk svær tid. Deres indkomst var stadig lav; i 1913 ikke over 700-900 $\mathrm{M}$ årligt. Uanset social status var der $\mathrm{i}$ realiteten allerede $\mathrm{o}$. 1880-1910 ikke mere den store forskel på Slesvig-fiskernes økonomiske situation, idet de stadigt dårligere fangster ramte alle fiskerne i Slesvig. Mange af småfiskerne langs med Slien gik derfor allerede i de første år efter 1900 tilbage til det landbrug, de var kommet fra.

Om ikke andet, så afdækkede striden 1869-1913 da, at Slesvigfiskerlavets og Arnæs-skippernes lokale magtstilling var gået tabt.

\section{Striden 1917-1935: Intensiveringen af fiskeriet giver nyt klammeri om Sli-silden}

De såkaldt gyldne tyvere var en politisk urolig tid med både inflation og arbejdsløshed. For arbejderen var 20'erne en fattig tid, der sved og bed; og arbejdsløse levede på eksistensminimum. Socialhjælpen vàr for ringe til, at en familie kunne leve af den.

Landbruget gik det ikke spor bedre. Den ene ejendom efter den anden røg på tvangsauktion, og med politimagt drog de ramte af gårde. Med landbrugets tilbagegang blev også industriens, handelens og håndværkets situation forværret.

Krisen var hård. Lokalt betød den ikke kun arbejdsløshed blandt 


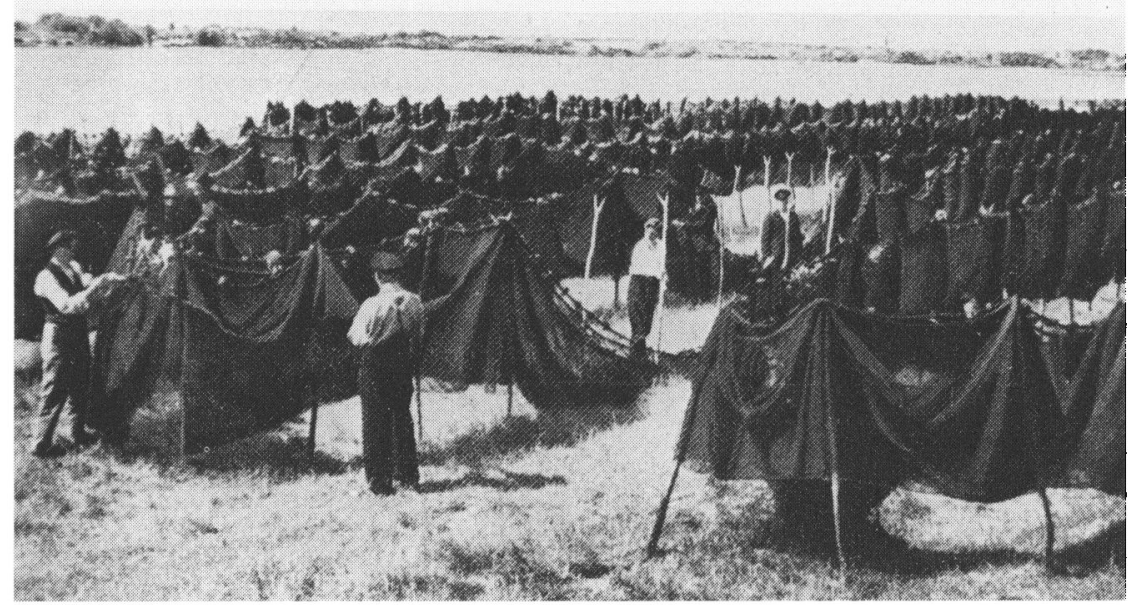

Udsnit fra nettørrepladsen Friheden lige øst for fiskerlejet Holmen, hvor Slesvigs fiskere torrede deres garn. Ca. 1930-1934.

industriarbejderne i Kappel, landarbejderne og daglejerne, men også en stopper for Arnæs' turistindustri. På en eller anden måde skulle alle disse folk klare sig, og her var der kun én mulighed: at fiske småt på Slien. Konsekvensen blev en intensivering af fiskeriet, som medførte fornyet klammeri om Sli-silden. Striden varede helt frem til 1935. Selv i 30'erne fandtes der således arbejdsløse. Naziregimet glemte blot dets modstandere, som blev sendt ud i kulden: lige ind i arbejdsløshed.

Slesvigs vodfiskere vendte sig i 1917-1935 dog ikke så meget imod kommunerne langs med Slien, selv om småfiskeriet også tog til fra den kant. Kommuneforstanderne udstedte nemlig ikke kun fiskekort til kommunernes egne, men også til folk længere inde i Angel. Når det kom til stykket, var det dog kun forholdsvis få, der fiskede i erhvervsøjemed. Langt de fleste fiskede kun til privat forbrug. Som sagt, var Slesvig-fiskerlavets egentlige modstandere $\mathbf{i}$ striden ikke småfiskerne $\mathbf{i}$ kommunerne, hvis fiskeri tilmed løjede mærkbart af efter 1924. Det var derimod de 80 Arnæs- og 70 Kappel-fiskere. Arnæs-fiskerne var dog stadig Slesvig-fiskernes hovedmodstander, da begge kun fiskede i den øvre Sli. På trods af striden med Arnæs og Kappel øgede Slesvigfiskerne i 20 'erne deres indkomst fra 850-1100 M (1920) til 1500-1800 M (1930). Silden var igen kommet tilbage til Slien, og sildepriserne gode. Kun i 1923-1925 faldt Slesvig-fiskernes indkomst igen til 500$800 \mathrm{M}$ årligt. Alt i alt var 20 'erne dog et godt årti for Slesvigs fiskere; 


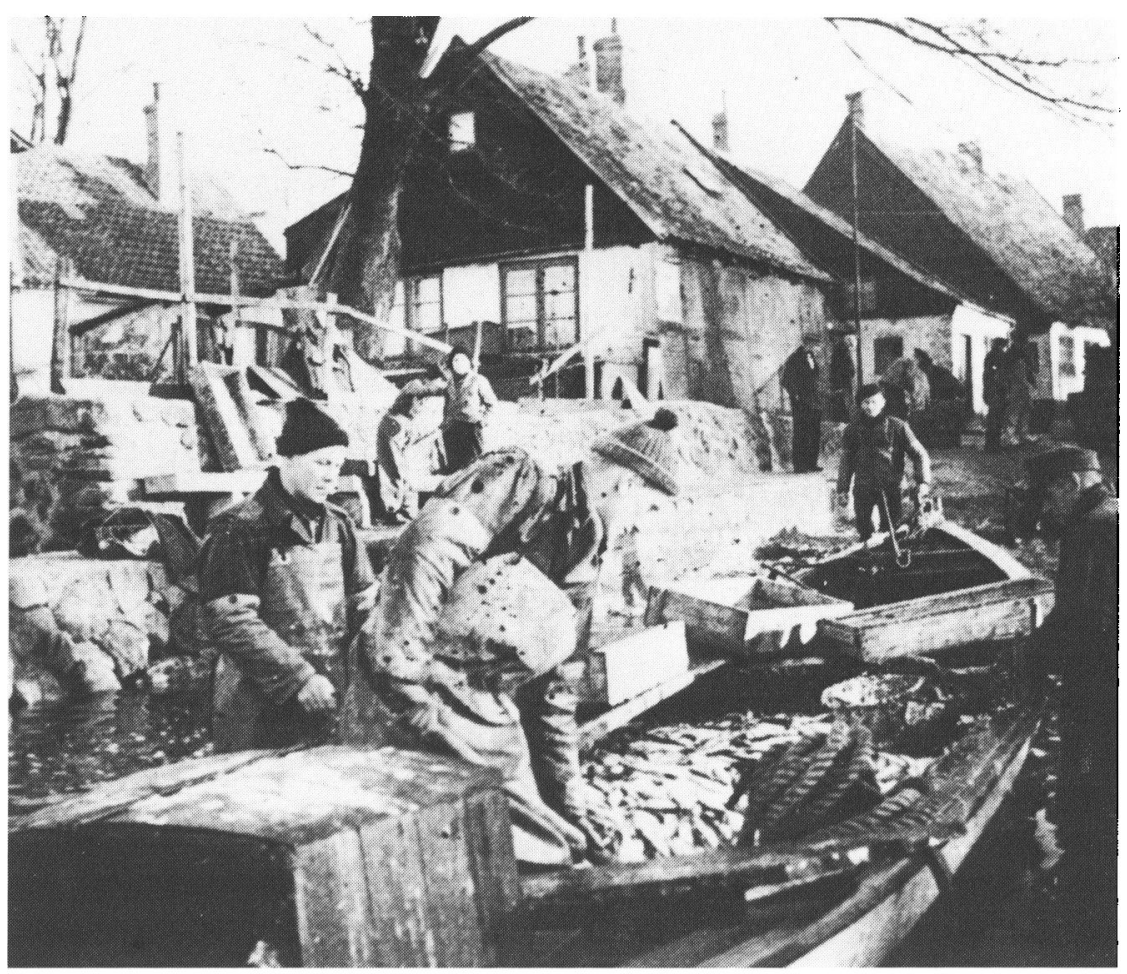

Fisk landes ved Nienstadt på fiskerlejet Holmen i Slesvig. Ca. 1950.

for nogle af dem endda så gode, at de købte sig et klaver. Fiskerne i Slesvig kaldte således i 20'erne Norderholmstraße for »de Klaverstraat«, på dansk: Klavergaden. De to eller tre vodfiskere, som havde et klaver, kunne dog ikke spille på det.

At det på trods af de gode sildeår i 20'erne alligevel kom til klammeri mellem Slesvigs, Kappels og Arnæs' vodfiskere, lå i en stærk indvandring af pommerske og østpreußiske erhvervsfiskere til Kappel og Arnæs. Det skete i 1916-1920, og for Arnæs endda også i 1909-1912.

Arnæs lokkede således $\mathrm{i}$ annoncer med, at man i flækken kunne købe huse med tilhørende fiskerirettigheder. Desuden var det en fordel at bo i Arnæs, da fiskerne i godt vejr kunne fiske langs kysten ud til Østersøen og i dårligt på den øvre Sli med dens gode fangstpladser. Uanset vind og vejr havde Arnæs-fiskerne altså altid mulighed for at tjene gode penge ved net- og vodfiskeri. Mens der endnu i slutningen af 1890 'erne var to erhvervsfiskere i Arnæs, steg tallet på grund af 
indvandringen til 6 i 1916 og 18 i 1929. Dertil kom så et utal af bierhvervsfiskere som håndværkere, pensionister og kroværter, der ved småfiskeriet fik sig en mindre, omend tiltrængt biindtægt. Fisken var et nødvendigt kosttilskud for disse småfiskere. De havde også fisket småt før 1914, men den dårlige levnedsmiddelsituation i de sidste krigsår tvang dem til at intensivere småfiskeriet.

Selv for Arnæs' egne erhvervsfiskere, som trak vod, blev Arnæsbierhvervfiskernes omfattende aktivitet med tiden for meget. Derfor opfordrede fiskerlavet i Arnæs 1929 Slesvigs fiskerlav til at stå sammen mod bierhvervsfiskerne. Bortset fra dette ene tilfælde var der stort set krig på kniven mellem Slesvig- og Arnæs-fiskerne. Slesvigs vodfiskere trak således Arnæs-fiskernes vod op af vandet eller fjernede andre af deres fiskeredskaber, når de stødte på dem i den øvre Sli. Arnæsfiskerne derimod gik straks mere radikalt til varks. De kastede med sten mod Slesvigs fiskere og overhældte deres garn med syre.

Også Kappel fik som nævnt sine østpreußiske og pommerske fiskere. Konkurrencen herfra fik erhvervsfiskerne i Kappel til at flytte deres vodfiskeri fra den nedre Sli til den øvre, hvor man kunne fange flere sild. Oveni det kom, at en del af de dårligst stillede i Kappel fiskede småt helt ned til Den store Bredning og Ornum nor på Slien. De skulle jo leve, også under 20'ernes trange kår.

Slesvigs fiskere reagerede skarpt ved gang på gang at trække Kappelfiskernes net op af vandet, når de stødte på dem i den øvre Sli; og dem var der i 1919 hele 120 af. Det var mange. Fiskerne i Kappel var rasende og truede med at gennemtvinge retten til fiskeri i den øvre Sli, hvis ikke holmerne holdt op med deres chikaner. Skulle det blive nødvendigt, ville Kappels fiskere endda tvinge sig til retten ved at bruge magt.

I takt med, at striden frem til 1925 blev skærpet, rykkede også Kappel-fiskerne tættere sammen. Mens Kappels fiskerlav i 1917 således kun bestod af ca. 10 erhvervsfiskere, steg tallet i 1920 til 49 og 1923 til 70. Af disse 70 fiskere var $80 \%$ bierhvervsfiskere. Dette viser, at antallet af erhvervsfiskere i Kappel i 1917-1923 kun var steget fra 10 til 14; men også, at småfiskerne, der drev fiskeri som bierhverv, indså nødvendigheden af at være organiseret. De var lige så fagligt bevidste som erhvervsfiskerne, der trak vod. Disse affandt sig dog ikke med bierhvervsfiskernes dominans i Kappels fiskerlav, da småfiskerne tog brødet ud af munden på dem. Derfor startede Kappels erhvervsfiskere i 1929 et nyt fiskerlav, som fik 19 medlemmer. Indtil da var det dog flere gange kommet til stærk indbyrdes strid mellem erhvervs- og 


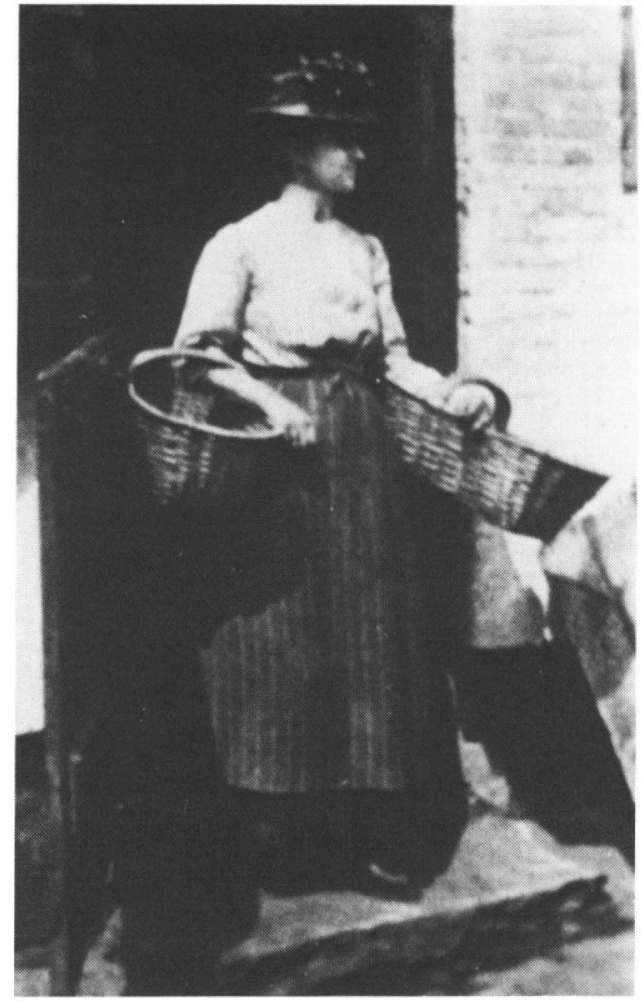

Minna Fischer var en fiskekone, som boede på Holmen. Hun var en af de kvinder, der falbod Slesvig-fiskernes fisk inde i Slesvig; fisk, som de bar på $i$ deres flettede kurve. Minna Fischers mand var Slesvig-fisker. Fiskesalget var disse koners levevej. De kobte selv fiskene of Holm-lavets fiskere. Disse kvinder nod altså en selvstandig stilling blandt fiskerne pả fiskelejet. Det var pả en måde dem, der udgjorde den daglige kontakt mellem Holmens fiskere og det ovrige Slesvig. Ca. 1900-1920.

bierhvervsfiskerne i Kappel. Interesserne var for forskellige til, at de kunne forenes i et fiskerlav.

Modsætningerne mellem Slesvigs og Kappels erhvervsfiskere førte direkte ud i en retssag, som nåede helt op til højesteret i Leipzig, der i 1924 afgjorde, at fiskerne i Kappel kun måtte fiske ned til Siseby på den øvre Sli. På trods af kendelsen fortsatte striden frem til 1929, og udløbere endda frem til magtskiftet i Tyskland 1933.

Indtil da forsøgte Slesvigs fiskerlav selv at klare ærterne ved, i 1925-1934 at ansætte en af sine egne fiskere som fiskerikontrollør på den øvre Sli. Han var aflønnet af Slesvigs magistrat og fiskerlavet i fællesskab, og tålt af Oberfischmeister Neubaur, som han stod i kontakt med. Neubaur var den øverste tilsynsførende for fiskeriet i SlesvigHolsten. Alle klager blev således via Slesvig-fiskernes fiskerikontrollør ledt videre til Neubaur. På mig virker det nærmest, som om fiskerikontrolløren i sin embedstid for igennem sivene på jagt efter syndere, der 
kun fiskede til privat forbrug. Her blot et eksempel blandt mange: „Da jeg tog retning af båden, løb først Schiwek i land, gemte redskaberne ... og cyklede væk. Så løb (hans medfisker) Jensen i land; også han ville cykle væk. Jeg råbte, tre gange: "Stands, eller jeg skyder!«, men han overhørte det. Selv et advarselsskud overhørte han, og cyklede væk; men Kruse, en arbejder, fik jeg fat $i$, beslaglagde hans fiskestang og en bylt med tre aborrer $i$... også en med seks, som jeg fandt $i$ skjulet« (oversat fra tysk).

Der var helt klart tale om selvtægt fra fiskerlavets side, idet kontrollørens opgave var at rense ud blandt Kappel- og Arnæs-fiskerne, der jo fiskede på Slesvig-fiskernes vodpladser i den øvre Sli. Især Arnæsfiskernes netfiskeri var sine steder så omfattende, at nettene lå så tæt, at skibe kun lige kunne sejle igennem.

Fiskerlavet i Slesvig krævede derfor, at Arnæs- og Kappel-fiskerne skulle organiseres $i$ et fælles fiskerlav, som var underlagt de samme skrappe bestemmelser som Slesvig-fiskernes lav. Derved ville man ikke kun undgå enhver videre strid om Sli-silden, men også opnå, at Kappels og Arnæs' fiskerlav ikke længere bekrigede hinanden til stor skade for "alle andre«.

Forslaget afvistes. I stedet ansatte Arnæs-fiskerne deres egen fiskerikontrollør, der skulle forhindre, at Slesvigs fiskere trak vod på Slien mellem Arnæs og Lindånæs, hvor Slesvig og Arnæs delte retten til Sli-fiskeriet. I 1926 planlagde man derfor at regulere Sli-fiskeriet på andelsbasis, men Slesvigs magistrat gik imod: "Noget sådant ville blot irritere folk i Slesvig unødigt; og især Slesvigs fiskere, der som trofaste tyskere er vigtige for byen. Vi er blevet tvunget til at kæmpe for vor bys og Nordmarkens tyskhed. Det kan derfor kun være i provinsregeringens interesse at støtte tyskerne i Slesvig. De seneste års fejlslagne nordmarkpolitik har allerede ført til, at der $\mathrm{i}$ det hidtil rent tyske kredsudvalg nu sidder to danskere. Dette viser tydeligt, at den danske fare for Slesvig på ingen måde er blevet mindre ... Slesvigerne har en udpræget sans for deres egenart; og da de sejt fastholder gamle rettigheder, vil en sådan tvangsforanstaltning blot være en ny, stor politisk fejl.« (oversat fra tysk)

I ramme alvor mente Slesvigs magistrat, at en andelsregulering af Sli-fiskeriet ville kunne give Slesvigs fiskere danske sympatier, fordi de under Danmark altid var blevet behandlet godt af den danske stat. Den holdning kom dog først helt tydeligt frem i 1931. Først naziregimets såkaldt ordnede samfundsforhold skabte imidlertid endeligt ro om Sli-silden. 
Striden om Sli-silden drejede sig i grunden kun om at få dækket to helt fundamentale behov: mad og penge. Klarest kom det til udtryk $\mathrm{i}$ striden med Slesvigs magistrat om, hvorvidt fiskerlavet eller magistraten sad inde med den formelle ret til fiskeriet på Slien. Striden varede fra 1915 til 1928. For Slesvigs magistrat gjaldt det om at sikre byen en konstant forsyning af fisk; og for fiskerlavet gik det om at sikre dets indtægter. Magistraten skulle garantere, at den ikke ville bortforpagte fiskeriet på den øvre Sli til andre end fiskerlavet i Slesvig. Kravene blev imødekommet $\mathrm{i}$ forliget af 1928, der uvist af hvilken grund først trådte i kraft 1933.

At Slesvig-fiskernes indtægter alligevel ikke var sikret, viste omsvinget fra først i 30'erne, da 70\% (1931) af lavets 84 fiskere enten var arbejdsløse eller fik socialhjælp. I 1922 havde fiskerlavet i Slesvig endnu haft 120 fiskere. Slesvig-fiskernes økonomi var frem til 1935 altså ikke for god. Først i 1935 fik nemlig en del af dem arbejde ved byggeriet af kasernen Die Freiheit, som var et led i nazi-regimets genoprustning. Arbejdet havde dog sin pris. Det fratog dem næsten hele deres tidligere så store nettørreplads Friheden, som lå lige op til fiskerlejet Holmen. Der blev kun en smal bræmme tilbage.

\section{Striden 1805-1935}

På langt sigt fik striden to konsekvenser. En af dem har jeg nævnt. Det var, at 1800-tallets voksende demokratisering og liberalisering af samfundet også demokratiserer og liberaliserer sildefiskeriet på Slien. Resultatet var i 1935, at Sli-fiskeriets privilegieorienterede økonomiske struktur var afløst af en friere økonomisk struktur; og, vel at mærke, at fiskerne i Slesvigs fiskerlav langt om længe indså dette. Endnu i 20'erne havde man således over for Arnæs og Kappel argumenteret med sine privilegier, og her især Christian 1.s Sli-brev fra 1480. Også andre end Slesvigs fiskerlav havde altså nu ret til at fiske på Slien. Som i alle årene blev der også fisket andet, men silden udgjorde stadig Slifiskernes hovedindtægtskilde.

På den anden side betød samfundets åbning og den økonomiske udvikling en kulturel katastrofe for Arnæs-skipperne og Slesvig-fiskerne. Arnæs' skipperlav og Slesvigs fiskerlav havde hver især været rammen om en skipper- og fiskerkultur. Det betød, at Arnæs' skippere og Slesvigs fiskere kun magtede at værne om deres egen kultur, så længe de kunne fastholde deres stærke lokale stilling. I årelange rets- 


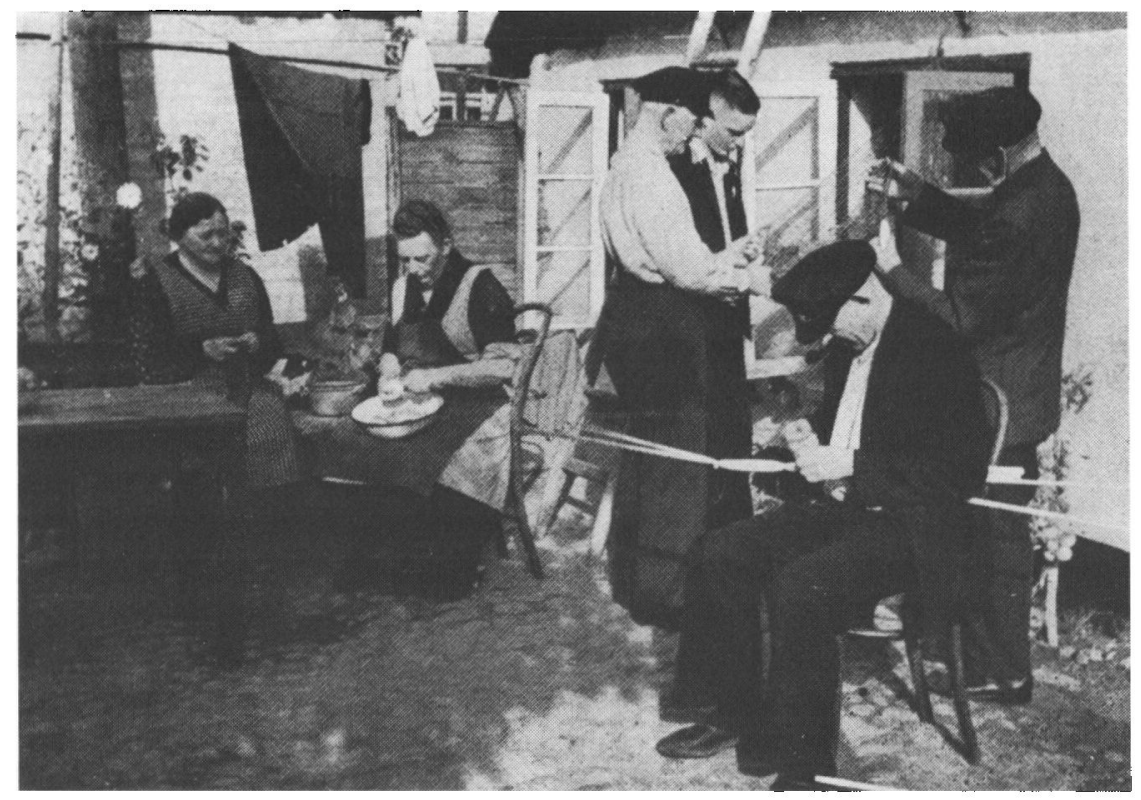

Sondag formiddag. Inde i gården til et af Holmens fiskerhuse lapper Slesvig-fiskere net, mens fiskerkoner skraller kartofler og strikker. Situationen giver et godt billede af arbejdsdelingen i fiskerfamilierne på Holmen; dog var det ikke ualmindeligt, at kvinderne lappede net. En parallel hertil ses $i$ landbruget, hvor kvinden tidligere også stod for det huslige arbejde, samtidig med at hun arbejdede med $i$ bedriften på lige fod med manden.

trætter bidrog de selv til at nedbryde denne deres almuekultur. Hvor udpræget den har været i Kappel, ved jeg ikke. Kappels erhvervsstruktur var jo på intet tidspunkt så ensidig som Arnæs'; og Kappel forstod også bedre at omstille sig til den nye tid. I hvert fald fandt industrikulturen sit indtog i Kappel i takt med, at mindre industriforetagender søgte til byen.

I dag er Kappel et lokalt centrum for egnen, mens Arnæs så godt som kun lever af turismen. Om vinteren er den stort set død. Af fiskere på Holmen er der ikke ret mange tilbage, og de få der endnu er, føler sig som slesvigborgere.

\section{LITTERATUR OG KILDER}

Archivrat Dr. Kupke: Die Stadt Schleswig und ihr Anrecht auf die Schleifischerei, Schleswig 1916 (pjece) 
Justitzrat Dr. Baumert: Das Recht der Schleswiger Fischer an der Schleifischerei. Eine Entgegnung, Schleswig 1917 (pjece)

Stadtsyndikus Mielke: Das Fischereirecht der Stadt Schleswig und die Errichtung einer Fischereigenossenschaft für die Schlei, u.å. (duplikeret papir)

Ernst Vollertsen: »Holmen - et fiskerleje«, Sønderjysk Månedsskrift 1978, s. 100-105 og 142-146

Nils Vollertsen: „Fiskerlejet midt i købstaden. Om kvarteret Holmen i Slesvig ca. 1800-1910«, Folk og Kultur 1984, s. 34-51

Nils Vollertsen: „Øgenavne og levevilkår blandt fiskerne i Slesvig«, Sønderjyske Årbøger 1985 , s. $137-156$

Desuden er anvendt et omfattende kildemateriale fra 1: Archiv der Holmer Fischerzunft, Schleswig; 2: Landesarchiv Schleswig-Holstein, Schleswig; 3: Stadtarchiv Kappeln; 4: Stadtarchiv Schleswig. I alt er der tale om 138 numre. At gengive dem udførligt, ville fylde for meget $i$ forhold til artiklens størrelse. Jeg har derfor valgt kun at nævne numrene og i stedet prioritere det billedmateriale, jeg indsamlede på Holmen samtidig med øgenavnene i 1978-1980. Fotografierne blev affotograferet af Klaus Reincke, Slesvig.

De anvendte kilder er fra 1: I, II, III, 2, 2a, 4, 6, 13, 15, 15a, 19, 27, 28, 29, 30, 31, 36, $37,40,42,63$, protokoller 1946-1975 og 1912-1945; fra 2: Abt. $50 \mathrm{c} \mathrm{nr.} \mathrm{7,} \mathrm{2190,} \mathrm{2534,}$ Abt. 66 Req. IVb nr. 6, 55, Abt. 79.3 (Schl. Minist. I. Dep. A-B und II. Dep. B) nr. 186, 426, 436, Abt. 79 nr. 991a, 991b, 991c, 991d, Abt. 168 nr. 197, 198, 199, 200, 201, 2209, Abt. 309 nr. 8325, 8544, 12267, 12272, 12369, 12370, 12371, 17512, 17766 , $20679,30864,34449,34494,34495,34497,34499$, Abt. 313 nr. 16-23, 46-49, 50-51, 53-55, 57, Abt. 320 Schleswig L. nr. 463, 464, 465, 468, Abt. 333 nr. 20, Abt. 352 LG Kiel nr. 236; fra 3: Abt. 1/10 nr. 4, 7, 28, Abt. 2/26 nr. 170, Abt. 3/19 nr. 394; fra 4: C XIX-3 nr. 251, 251a, 251c, 251f, 251g, XIII-1 nr. 1, 2, 3, 4, 5, XIII-2 nr. 1, 2, 3, 5, $6,7,8,9,10,11,12 \mathrm{a}, 12 \mathrm{~b}, 12 \mathrm{c}, 12 \mathrm{~d}, 12 \mathrm{e}, 12 \mathrm{f}, 12 \mathrm{~h}, 12 \mathrm{l}, 12 \mathrm{~m}, 12 \mathrm{n}, 12 \mathrm{o}, 12 \mathrm{q}, 12 \mathrm{~s}, 12 \mathrm{t}$, $12 \mathrm{u}$, XIII-3 nr. $1,2,3,4,5,6,7,8,9,10,11,12,13,14$, XIII-4 nr. $1,2,3,6,8,9$, 10

Jeg har bestræbt mig på at gennemgå så godt som alt eksisterende materiale om striden om fiskerirettighederne på Slien, og alligevel har huller i fremstillingen om Slikommissionens arbejde ikke kunnet undgås. Det ligger $i$, at en stor del af materialet fra Sli-kommissionen ifølge nogle kilder allerede omkring 1900 var gået tabt, eller $\mathrm{i}$ hvert fald ikke mere forefandtes. Af disse kilder fremgår dog ikke pracist, hvilke papirer der var tale om. Så vidt jeg kan se, må der tildels have været tale om nedenstående kilder fra det slesvigske ministeriums arkiv (Abt. 79) og det tyske kancellis arkiv (Abt. 65). Disse kilder forefindes hverken på det slesvig-holstenske landsarkiv i Slesvig eller Rigsarkivet i København, men burde ifølge en gammel registrant have ligget i 4: Abt. $65 \mathrm{nr} .861$, Abt. 79 nr. 55, 56, 58, 426.

Mit systematiserede materiale og den tekst, hvoraf artiklen her er et ekstrakt, ligger i byarkivet i Slesvig, hvor enhver frit kan se det. 